DOI: 10.2478/atd-2019-0016

\title{
ARTICLES
}

\section{Ethnopedagogy: The Term and Content}

\section{Ildikó Sándor*}

Received: September 3, 2019; received in revised form: November 4, 2019; accepted: November 6, 2019

\begin{abstract}
:
Introduction: This study reviews the most commonly used Hungarian terminology of pedagogical folklorism terms, their interpretations and the conceptual debates around them, as well as the possible imprecisions related to them. With the help of Hungarian and international examples, it places the technical terms of the ethnography-folk tradition-pedagogy triangle into a system and finally, it gives recommendations on the scientific terminology to be used to describe the phenomenon.

Purpose: The focus of this contribution is to create a system in the expressions that refer to the relationship between folk tradition and pedagogy and to carry out the systematisation of pedagogical activities related to folk tradition/ethnography and to rethink them in a modern and terminology-critical manner.

Methods: In the present study, we applied source analysis, content analysis, logical operations (analysis, synthesis, comparison).

Conclusions: Researchers of the issues at the intersection of pedagogy, ethnography, ethnology and anthropology have more or less consistently been applying the term ethnopedagogy for this interdisciplinary research area. It would be expedient to carry out the systematization of pedagogical activities related to folk tradition/ethnography and to rethink them in a modern and terminology-critical manner with the introduction of the term "ethnopedagogy." This term may be able to connect the partially overlapping, sometimes parallel (at others, contradicting) terms related to the pedagogy of folk tradition without the risk of homogenisation.
\end{abstract}

Key words: terminology, pedagogical folklorism, folklore education, ethnographic knowledge, folk tradition, safeguarding and bearing traditions, educanthropology, ethnopedagogy.

\footnotetext{
* Ildikó Sándor, Hungarian Dance Academy, Budapest, Hungary; dr.sandor.ildiko@gmail.com
} 


\section{Acta Educationis Generalis \\ Volume 9, 2019, Issue 3}

\section{Introduction}

The present study reviews the most commonly used Hungarian terminology of pedagogical folklorism, their interpretations and the conceptual debates around them, as well as the possible imprecisions related to them. With the help of Hungarian and international examples, it places the technical terms of the ethnography-folk tradition-pedagogy triangle into a system and finally, it gives recommendations on the scientific terminology to be used to describe the phenomenon. László Trencsényi (1992) already emphasised at the conference organised in 1992 in Jászfényszaru that "the pedagogical interpretation of ethnographic terms is necessary, as the use of terminology is often arbitrary, many underpin their own practices with fashionable words, and consequently the same terms are used to describe different practices."

The introduction of the National Core Curriculum (NAT) in 1996 did not bring about significant changes in terms of terminology, although the year was a turning point in Hungary's pedagogical history: the previously scattered attempts to elevate folklore literacy to the level of school curricula and subjects that formerly appeared rather as alternative ways to pedagogy, were thus incorporated in the educational palette as separate, compulsory subject areas ("homeland and peoples" and "dance and drama"). It is quite telling that the title of the volume of studies (Karácsony \& Kraiciné, 1998) - Homeland and peoples, folk tradition in the educational activity - published after the conference preceding the introduction of NAT that involved all relevant experts of the area lacked the summarizing-synthesising expression and had to enlist the elements of the field instead.

We have often encountered the above problem and all its difficulties: how could we define the topic of our presentations, studies (folklore literacy in pedagogy) in a comprehensive, unbiased manner? In the subtitle of the volume of studies (Benedek \& Sándor, 2006, 2010) entitled Útravaló [Viaticum], with my coeditor, we chose the slightly cumbersome expression "passing on traditions." Our idea was to ensure that all experts and professionals who are involved in either branch of the area (such as teachers of folk dance, folk music or handicrafts) or in fact represent a different stance in terms of objectives and methods (for example teaching ethnography or ethnology, the safeguarding and living of traditions) identify themselves with the expression.

The aforementioned conference organised in 1996 seems like a good starting point for the analysis of this terminology. The presenters of the conference included representatives of the most important initiatives of the pre-NAT era (e.g. courses on homeland studies, pre-school programmes aimed at the safeguarding of traditions), the entire education spectrum (from pre-school up to the respective higher-education institutions), as well as representatives of the science of ethnography, and practitioners involved in the passing on of traditions. The presentations of the conference in 1996 covered all forms of education: formal, non-formal and informal, thus the alternative reform efforts 


\section{Acta Educationis Generalis \\ Volume 9, 2019, Issue 3}

(and the related terminology) of the previous period, as well as the cultural learning, bottom-up, civil organisation character of the dance-house movement and the folk arts and handicrafts workshops, together with their methods and terminology were granted room in the publication. If we attempt to create a system in the 30-40 expressions that referred to the relationship between folk tradition and pedagogy in the various presentations at the conference in 1996, we can detect three larger categories:

- expressions referring to the teaching of a particular subfield of folk tradition;

- technical terms of ethnography;

- pedagogical terms.

\section{Expressions for subfields of folk tradition}

- folklore education;

- teaching folk poetry;

- "traditional instrumental music pedagogy", "traditional ways of learning folk music", learning folk singing;

- teaching/learning folk dance; dance education; children's dance;

- the role of folk customs in educational activities;

- (the role of) folk games in education;

- teaching folk arts (in a narrower sense: object design and decorative art) and as a synonym of the latter, handicrafts, handicrafts education; and a part of it, teaching traditional weaving.

Folklore education indicates intangible cultural heritage, clearly delineating it from material artefacts. The presentation of Szabóné Gulyás (Karácsony \& Kraiciné, 1998, p. 271) however, clearly shows that students of the primary school teacher training in Jászberény studied both tangible and intangible ethnography in the framework of the activities of their college, extended by museology and artwork protection, as well as field trips and internships at museums. Coining all these activities with the terms folklore or folkloristics is not correct, as all the most important subfields of ethnography appear in the curriculum.

The interrelationship of folk music and pedagogy appears in the aforementioned conference material in several ways. Using the term "traditional instrumental music pedagogy" Agócs presented the results of his field research, giving an insight into the instrument learning institutions and methods of music specialist families ${ }^{1}$. The traditional ways of learning folk music expression in Juhász's presentation deals with the issue whether the methodology of traditional instrument learning can be adapted to the framework of institutional music

\footnotetext{
${ }^{1}$ One chapter of Agócs's doctoral dissertation discusses this topic in detail.
} 


\section{Acta Educationis Generalis \\ Volume 9, 2019, Issue 3}

education. Bodza discussed ways of learning folk singing (Karácsony \& Kraiciné, 1998, p. 151) in her presentation. Differentiating between instrumental and vocal music is not only reasonable in the scientific approach, but also in the practice of teaching (folk) music, as pupils learning singing and instruments attend different faculties of elementary arts schools as well.

Several different expressions are used for folk dance pedagogy as well. Amongst these, the term children's dance (Karácsony \& Kraiciné, 1998, p. 129) requires explanation, as it covers more than it seems at first glance, namely the restriction to age. The term originates from art of movement (orchestics) pedagogy of the early 20th century and the related children's art concept, while its folk dance pedagogy relevance comes from the folk dance pedagogical book that focused on this particular age group of children entitled "Gyermektáncok" (Children's dances) (Sz. Szentpál, 1959). The authors of this book included the most important figures of Hungarian orchestics and folk dance pedagogy of the time (Szentpál, Magyary, Györgyfalvay, Endréné Osskó, Szigeti, és Kaposi). Undoubtedly, here we have to define dance in a narrower sense - that is, as folk dance - since the book's teaching material is clearly derived from the dance folklore. Here I would like to point out that Sándor Tímár used the term culture of movement (Karácsony \& Kraiciné, 1998, p. 133) and thus placed folk dance teaching into a broader context, which is also supported by the fact that he attaches great importance to the teaching of folk games as well.

The terms used to describe the "whole" (terms with general meanings of traditional culture) - tradition, folk tradition, traditional, Hungarian folk tradition, folk culture, ethnography/ethnographic knowledge - are discussed in the next section, as these are primarily related to the science of ethnography.

\section{The scientific terminology of ethnography}

- knowledge on homeland and peoples, ethnography, anthropology (cultural anthropology);

- tradition / folk tradition / traditional / Hungarian folk tradition;

- folk culture;

- ethnography (ethnographic knowledge).

The Hungarian term for ethnography points towards German history of science roots, to which it was connected with a thousand ties bonds in the decades that followed the establishment of the Hungarian scientific field, e.g. in the field of pedagogy as well, as we can see in the article of Virág (2019). The term (cultural) anthropology however refers to a more recent Anglo-Saxon orientation. Although the topics and methods of the two disciplines are closely related, they cannot be used as synonyms.

Using the words folk and tradition as technical terms bears several risks, however, defining their meaning and placing them in the system of terms is 


\section{Acta Educationis Generalis \\ Volume 9, 2019, Issue 3}

unavoidable. They are similar in that in popular speech they cover a constantly changing, broad variety of meanings. In scientific use however, they need to be clarified and be used cautiously and critically.

The prefix word folk is being used by most subfields to describe their subject (folk dance, folk poetry, etc.) in order to delineate it from high art or professional arts. The technical term for the discipline itself is ethnography. Some experts use the term folk (ethno) in a broader sense, some in a narrower. Györffy (1939, p. 5-11) uses the term folk to describe the lower, subordinate layers of society, contrasting it with the "aristocratic" or higher layers. It relates to the term "national" through the idea that the "folk" represents a part of nation understood as a political community (therefore Györffy differentiates between folk tradition and national tradition). In Andrásfalvy's works (2004) however, we see a broader meaning, as he often uses hyphenation to connect the two elements that Györffy differentiates: folk-national. We get a more nuanced explanation from Kósa (1984, p. 11-13), who - in addition to the geographically determined cohesion (a settlement/region/country) - widens the notion of folk with three additional factors (and narrows it at the same time compared to Andrásfalvy for example):

- subordinated classes, layers;

- who gain their livelihoods from manual labour;

- whose relationship to culture as tradition is similar and is based on identity and continuity.

The expression ethnos (Sárkány, 1977, p. 745) - although not to be found in the terminology of pedagogy - may be suitable to replace the word "folk." In terms of the subfields however, its application would not be ideal (ethnomusic, ethnodance or ethnoart), although the terms ethnomusicology, ethnochoreology are nowadays commonly used. Still, being aware of the definition of ethnos will be useful for the following sections - "a historically evolved group of people, who share relatively stable cultural features, and are aware of their identity and the difference it shows to other groups." It is a historical category and is therefore capable of change and is a changing phenomenon in spite of the fact that "it may give the impression of cultural permanence."

In popular speech (and thus in several pedagogical works), the expressions tradition and traditional are used to describe "ancient" elements of literacy, that in fact are no longer present in recent culture, which in an ethnographic sense is incorrect. Special attention must be paid to ensure that tradition is not being used as a synonym to folk, as there are many different types of traditions.

Nyíri (1994, p. 7) refers to tradition as "the knowledge-preserving institution of orality", which is the "precondition for the continuity and survival of societies" ensured by passing down cultural heritage from generation to generation. The term covers tangible culture and customs, actions and methods, i.e. social practice. We also have to take into consideration the unique relationship between 


\section{Acta Educationis Generalis \\ Volume 9, 2019, Issue 3}

tradition and innovation. Nyíri describes this as a phenomenon that works as follows - "depending on the circumstances, it changes as a necessity, however, with the sense of consistency." Nyíri applies the term primary tradition to the entirely orality-based culture of archaic societies (primary orality). With the appearance and - as a result of printing - spread of literacy, the role of orality and the way it works changed significantly; this is the era of secondary orality, in relation to which we can talk about remnant tradition and artificial tradition. "As a result of printing, traditions gradually lose their importance, the expression itself, and the word "tradition" gains broader and broader meanings." (Nyíri, 1994, p. 28).

Peoples studies - "the branch of domestic ethnography that places the study of the domestic peoples and their environment in centre." (Andrásfalvy, 2004, p. 107). From the remaining terms Hungarian folk tradition and homeland studies are the ones that are most strongly connected to the above one. The expression homeland studies - which once was a popular extra-curricular subject in schools - does not only include the study and understanding of ethnographic phenomena, but also the topics of dialects and local history. Accordingly, it is a term that is strongly related to ethnography, but - in certain aspects - is a broader concept, which at the same time narrows its topic by applying geographical constraints and by concentrating on local characteristics. Recently in Slovakia, a new curriculum entitled regionalism was introduced, which we discuss later on.

It should be mentioned that in the light of the tendencies in the use of terms that appeared at the 1996 conference, it is the expression ethnography that best links to the pedagogical direction which typically focuses on education, on passing on folk tradition related knowledge. The term tradition in contrast is being used for the experience-oriented, primarily art pedagogical direction (the safeguarding, the transmitting, the nurturing and the living of traditions). This observation however already leads us to the examination of the terms used in pedagogy.

\section{Pedagogy-related expressions}

- teaching - education - learning, acquisition, knowledge, optional subjects;

- transmission - transfer;

- $\quad$ safeguarding traditions - nurturing traditions.

The pedagogical terms illustrate the conception differences in the objective method - frameworks of the broadly defined system of pedagogy. The expressions in the first group - educating, teaching, knowledge, acquisition, learning - are clearly defined, widely known and used technical terms of pedagogy. The differences in the use of terms in Hungarian (e.g. folk music education used in a school framework - musical education used in a pre-school context) reflect on the views regarding the role of institutional education (preschool, school) and the relationships between teachers, pupils and the curriculum 


\section{Acta Educationis Generalis \\ Volume 9, 2019, Issue 3}

(the summative work "Didaktika" by Falus (2007) discusses the above terms and their internal system of relationships).

Although the expressions transfer and transmission are not technical terms per se, a pedagogical orientation can be detected when they are used in the context of transferring and transmitting knowledge or culture. Focusing on the question of how, they try to fit the inter-generationally, orally passed on, indirect methods of the rural culture, which are based on imitation, action and experience, to the framework of public education, together with the elements of folk tradition.

The focus of the remaining terms - bearing, safeguarding, living of/keeping traditions alive ${ }^{2}$ - is on cultural elements (e.g. folk customs related to various holidays, folk dance). The nuanced differences between the terms draw our attention to a very important approach-related question: should contemporary pedagogy establish a reproductive ("safeguarding") or rather an adaptive ("living of traditions/keeping traditions alive") relationship to the phenomena of folk tradition? Can customs, folk songs, games and folk-tales be transformed, and if so, to what extent and how? How much freedom does the teacher have in this respect, and what type of knowledge does he have to have to ensure that he can pass on his knowledge on traditional culture to his pupils with an appropriate level of expertise? And more importantly: why do we pass on folk traditions, what is the aim behind it?

Experts of ethnology - in Hungary and elsewhere - have long been dealing with the question what role folk literacy could have in contemporary culture. In an often quoted leaflet that had great impact, Györffy (1939) said that: "the role that we envisage for folk traditions is for it to serve as a basis for higher forms of literacy in all fields."

Some fifty years later, in a short piece on the present and future of folk culture, Kósa (1984, p. 109) writes: "Today, traditional folk culture is almost entirely experience." He also points out that the implementation of "the re-learning on a societal scope" (p. 134) has come to the foreground. Based on this observation he summarised the controversial issues related to re-learning. Andrásfalvy published his thoughts on this question around the turn of the century, and he also placed emphasis on the critical areas. Several speakers of the 1996 conference $^{3}$ also dedicated special attention to dilemmas and paradoxes of the transferability of folk (traditional oral) literacy in the framework of institutional education, often supporting, even extending the thoughts of Kósa and Andrásfalvy.

The pedagogical terms illustrate the conceptional differences in the objective method - frameworks of the broadly defined system of pedagogy.

\footnotetext{
2 The term „keeping traditions alive” does not appear in the book, but K. Papp has been using this expression for many years now, the written programmes of the kindergartens of Szentendre and Pomáz also use this term.

${ }^{3}$ Most dominantly, touching on several points and representing a definite standpoint: Ágh, Kraici, Gabnai, Vasvári, Barsi.
} 


\section{Acta Educationis Generalis \\ Volume 9, 2019, Issue 3}

The expressions in the first group - educating, teaching, knowledge, acquisition, learning - are clearly defined, widely known and used technical terms of pedagogy. The differences in the use of terms in Hungarian (e.g. folk music education reflect on the views regarding the role of institutional education (preschool, school) and the relationships between teachers, pupils and the curriculum (the summative work "Didaktika" by Falus et al. (2007), in which they discuss the above terms and their internal system of relationships).

1. Although the expressions transfer and transmission are not technical terms per se, a pedagogical orientation can be detected when they are used in the context of transferring and transmitting knowledge or culture. Focusing on the question of how, they try to fit the inter-generationally, orally passed on, indirect methods of the rural culture, which are based on imitation, action and experience, to the framework of public education, together with the elements of folk tradition.

2. The focus of the remaining terms - bearing, safeguarding, living of/keeping alive traditions - is on cultural elements (e.g. folk customs related to various holidays, folk dance). The nuanced differences between the terms draw our attention to a very important approach-related question: should contemporary pedagogy establish a reproductive ("safeguarding") or rather an adaptive ("living of traditions /keeping traditions alive") relationship to the phenomena of folk tradition? Can customs, folk songs, games and folktales be transformed, and if so, to what extent and how? How much freedom does the teacher have in this respect, and what type of knowledge does he have to have to ensure that he can pass on his knowledge on traditional culture to his pupils with an appropriate level of expertise? And more importantly: why do we pass on folk traditions, what is the aim behind it?

3. Experts of ethnology - in Hungary and elsewhere - have long been dealing with the question what role folk literacy could have in contemporary culture. In an often quoted leaflet that had great impact, Györffy (1939) said that "the role that we envisage for folk traditions is for it to serve as a basis for higher forms of literacy in all fields." (1939).

4. Some fifty years later, in a short piece on the present and future of folk culture, Kósa (1984, p. 109) writes: "Today, traditional folk culture is almost entirely experience." He also points out that the implementation of "the re-learning on a societal scope" (p. 134) has come to the foreground. Based on this observation he summarised the controversial issues related to re-learning. Andrásfalvy published his thoughts on this question around the turn of the century, and he also placed emphasis on the critical areas. Several speakers of the 1996 conference also dedicated special attention to dilemmas and paradoxes of the transferability of folk (traditional oral) literacy in the framework of institutional education, often supporting, even extending the thoughts of Kósa and Andrásfalvy. 


\section{Acta Educationis Generalis \\ Volume 9, 2019, Issue 3}

What aesthetic values are represented by folk tradition and by particular areas of folk art, respectively? There are over- and under-appreciating opinions, and also voices in the debate that question the independence and originality of folk arts. Additionally, Andrásfalvy warns of further dangers: undemandingness; a move towards kitsch in the effort of safeguarding traditions as a result of idealisation; and overly demanding programmes (compulsory shows, performances, competitions; quantities and types of materials that are not adapted to the target group's age). Those in favour of folk arts emphasise that it represents an independent and high level of aesthetic value, and as fundamental forms of artistic expression that appear in various forms (writing, movement, music, material artefacts), they are well-fitted to support the efforts aimed at enfolding children's personalities.

Does teaching Hungarian folk literacy bear the risk of nationalism, of an ethnic isolation, or does a better understanding of one's own culture and the presentation of the values thereof contribute to a higher respect for other cultures? The ideological, moral and aesthetic value aspects cannot be avoided when answering these questions, especially taking into consideration that both ethnography and pedagogy have their own unique (and from time to time changing) stances on the above issues.

\subsection{International outlook}

\section{The cultural anthropology (ethnology) approach in the USA}

As a result of the system-level failures of the US education system, the question arose in the 1950s how a better understanding of the cultural factor (different languages, ethnicities, cultures) could make education more efficient, more successful. In the schools of the "melting pot of peoples" difficulties in teaching arose both from the linguistic differences (Hispanic and Latino students) and from the different cultural backgrounds (Afro-American and Native American students, with high levels of English knowledge but different cultural backgrounds to the majority). Teachers and cultural anthropologists jointly sought answers to the above question.

Having examined the Hispanic, Afro-American, Native American and "Yankee" cultures in the South-Western part of the States (1959, New Mexico), they came to the conclusion that teaching methods and subjects (curricula) depend on the population, ethnicity by which it was created and is applied; the structure of education is characteristic of the ethnic community. Anthropologists supported these conclusions with their field experiences and by means of additional various school experiments (space, time, community relations, etc.) with very telling examples.

In the book summarising the results of the research and the school model experiments published in 1968, Burger hesitates when searching for a term for 


\section{Acta Educationis Generalis \\ Volume 9, 2019, Issue 3}

the discipline that was taking shape on the intersection between pedagogy and ethnology/anthropology. He mentions the term "educanthropology" coined by Grinager (from blending the words education and anthropology), and later uses the terms 'applied educational ethnology', cross-cultural educational methods and ethnopedagogy. However, he only provides a definition for the term ethnopedagogy. In the book, we can find several similar explanations on what ethnopedagogy is:

- "a term to describe teaching techniques when applied across cultures", or elsewhere shorter: cross-cultural educational, or elsewhere shorter: crosscultural educational/pedagogical methods;

- ethnopedagogy is the term for cultural anthropology (anthropological elements) applied in education.

Burger also deems it necessary to separately define both words of the blended term: Ethno = relating to cultures/across cultures; Pedagogy = "the art, science or profession of teaching"; and ethnopedagogy is the cross-cultural teaching activity (i.e. stemming from ethnic specificities, taking cultural specificities into consideration).

\section{G. N. Volkov and his followers}

There are some resources (Tufekcic, 2012) that claim that it was G. N. Volkov who first used the term ethnopedagogy, approximately at the time of the evolution of pedagogical anthropology in the US. It is however certain the title of his doctoral dissertation defended in 1967 already contained the word. Furthermore, in 1971 he established an Ethnopedagogical laboratory (under this title) in the framework of the Institute of Family and Education of the Russian Academy of Science. Volkov's summative work "Etnopedagogika" written in Russian was first published in 1974 in Cheboksary, and later, in 1999, it was published as a script (Volklov, 1974, 1999) written for secondary school and university students of pedagogy in Moscow. Volkov's works mostly found followers in the former Soviet member states, primarily in Central Asia, and around the turn of the century in the Balkans as well.

According to the Russian researcher's definition, the subject of ethnopedagogy is the analysis of specificities and rules of folk (ethnic) education. To do so, he examines the interactions of pedagogical and cultural traditions, the social and educational process, and studies the educational methods and solutions applied by folk culture. By studying the system of relationships between intangible culture (folklore), language, customs and community, ethnopedagogy could provide an answer to what the means and methods of education, of becoming an adult within a given ethnic group are.

His focal areas include: 


\section{Acta Educationis Generalis \\ Volume 9, 2019, Issue 3}

- the child, as subject and object of education;

- role and function of education (e.g. preparing for work, moral education);

- factors of education (nature, playing, community, arts, religion, etc.);

- methods (showing example, order-instruction, practice...);

- means (primarily certain genres of text folklore - sayings, proverbs, riddles, myths, epics);

- its organisation (parent's associations, youth festivities).

In 1994, UNESCO announced the International Year of the Family. On this occasion, a conference (Rüütel \& Kuutma, 1996) was organised in Tartu with the participation of Scandinavian, Finno-Ugric (former Soviet) and Baltic experts: folklorists, sociologists and ethnologists gave presentations. The case studies presented the methods and specificities of passing on traditions within the family and of ethnic education (in the fields of knowledge transfer, magical specialists, telling fairy tales, singing traditions). In their presentations, the specialists used the terms folk pedagogy (narodnaja pedagogika) and ethnopedagogy.

The Slovak school system contains the subject Regional education and traditional folk culture as a curriculum recommendation. ${ }^{4}$ The optional, relatively loosely framed subject was brought to life in the spirit of UNESCO's efforts to protect intangible cultural heritage. Although the term intangible cultural heritage is a broader one than folk culture, in the countries of Central Europe, it is mostly associated with the phenomena of folk traditions. "Regionality" can appear in an integrated manner in various subjects at schools, furthermore, it can also take the form of extracurricular activities (choirs, day trips, free-time activities at school). Its goals include both getting to know (local) traditional folk culture and multiculturalism, that is respect for other cultures, as well as - in a folk arts-aesthetics respect - enfolding students' personalities and ensuring talent management.

The term ethnopedagogy is also used by the Brazilian "Educafro" programme of 2009. ${ }^{5}$ Fifty percent of the pupils in public education in Brazil are African Americans, however the share of those continuing their studies is much lower. The programme aims at changing this tendency. It uses the term ethnopedagogy to describe a type of education system that takes ethnic specificities into consideration and that attempts to solve the challenges of ensuring equal chances with the help of education based on anthropology. Its concept is related to the ethnology-anthropology based ethnopedagogical approach established in the 1950 s in the USA.

\footnotetext{
${ }^{4}$ http://www.statpedu.sk/sk/svp/statny-vzdelavaci-program/svp-prvy-stupen-zs/ prierezove-temy/ regionalna-vychova-tradicna-ludova-kultura/ and

http://www.statpedu.sk/files/articles/dokumenty/statny-vzdelavaci-program/regionalna _vychova .pdf

${ }^{5}$ https://www.scribd.com/document/274618778/Ppp-lei-vestibular
} 


\section{Acta Educationis Generalis \\ Volume 9, 2019, Issue 3}

\section{Conclusion}

The relationship between oral tradition and institutional education has become the focus of expert attention in various regions of the world from the mid-20th century on. Researchers of the issues at the intersection of pedagogy, ethnography, ethnology and anthropology have more or less consistently been applying the term ethnopedagogy for this interdisciplinary research area.

Ethnopedagogy studies the characteristics of oral tradition with respect to its content and methods, looks at the various education methods of different ethnicities/cultures and compares these with contemporary education. The research conducted on the basis of pedagogical terms and with the methods of ethnography-ethnology (field work, participatory observation) can be utilised in the practical activities of present-day educational processes. The three possible main directions of ethnopedagogical research and discourse in practical pedagogy are as follows:

1. incorporating elements of the oral lore into the framework of institutional education;

2. conscious and planned applying of the methods of knowledge transmission in teaching and education;

3. taking the culture-bound differences between students of different ethnicities into consideration, thus ensuring more effective and more successful education.

All phenomena of the folk tradition pedagogy of the "re-learning on a societal scope" can be applied to and interpreted in the context of the three-dimension coordinate system of Trencsényi.

1. Where is it to be found on the socialisation-personalisation axle?

2. In terms of the methods and processes applied, is it defined by knowledgetransfer, cognitive teaching or culture-reconstruction, action- and experience-based characteristics?

3. Is the relationship to oral tradition to be found in the field of reconstructive (the wish to pass on without changing) and adaptive, neologistic folklorism?

Taking the international examples into consideration, it would be expedient to carry out the systematisation of pedagogical activities related to folk tradition/ethnography and to rethink them in a modern and terminology-critical manner with the introduction of the term "ethnopedagogy." This term may be able to connect the partially overlapping, sometimes parallel (at others, contradicting) terms related to the pedagogy of folk tradition without the risk of homogenisation. 


\section{Acta Educationis Generalis \\ Volume 9, 2019, Issue 3}

\section{References}

Andrásfalvy, B. (2004). Hagyomány és jövendö. Lakitelek: Antológia Kiadó.

Benedek, K., \& Sándor, I. (Eds.). (2006). Útravaló. A néphagyomány módszereinek közvetitése az óvodában. Budapest: Hagyományok Háza.

Benedek, K., \& Sándor I. (Eds.). (2010). Útravaló 2. A néphagyomány módszereinek közvetitése az iskolában. Budapest: Hagyományok Háza.

Burger, H. G. (1968). "Ethno-Pedagogy": A Manual in Cultural Sensitivity, with Techniques for Improving Cross-Cultural Teaching by Fitting Ethnic Patterns. New Mexico: Southwestern Cooperative Educational Laboratory, Inc.

Falus, I. et al. (Eds.). (2007). Didaktika. Budapest: Nemzeti Tankönyvkiadó.

Győrffy, I. (1939). A néphagyomány és a nemzeti müvelödés. Budapest.

Karácsony, M. E., \& Kraiciné Sz. M. (Eds.). (1998). Hon- és népismeret, néphagyomány az oktató-, nevelömunkában. Budapest: Budapesti Tanítóképző Főiskola.

Kósa, L. (1984). Hagyomány és közösség. Budapest: Kozmosz Könyvek.

Nyíri, K. (1994). A hagyomány filozófiája. Budapest: T-Twins Kiadó.

Regionálna vychova a tradičná l’udová kultúra. Retrieved from http://www.statpedu.sk/sk/svp/statny-vzdelavaci-program/svp-prvy-stupenzs/prierezove-temy/regionalna-vychova-tradicna-ludova-kultura/

Rumo à construção coletiva do Projecto Politico Pedagógico - Educafro. Retrieved from https://www.scribd.com/document/274618778/Ppp-leivestibular

Rüütel, I., \& Kuutma, K. (Eds.). (1996). The Family as the Tradition Carrier. Conference Proceedings 1-2. Tallinn.

Sárkány, M. (1977). Etnosz. In G. Ortutay (Ed.), Magyar néprajzi lexikon I. (AE). Budapest: Akadémiai.

Sz. Szentpál, M. ed. (1959). Gyermektáncok. Néptáncgyakorlatok, játékok, játékfüzések, néptáncok az úttörö- és az általános iskolai táncszakkörök részére. Budapest: Tankönyvkiadó Vállalat.

Štátny vzdelávací program. Regionálna vychova a tradičná ludová kultúra. http://www.statpedu.sk/files/articles/dokumenty/statny-vzdelavaciprogram/regionalna_vychova.pdf

Trencsényi, L. (1993). A tiszta forrás vize - kólásdobozból. Iskolakultúra, 3(6), 90-96.

Tufekčić, A. (2012). Osnove etnopedagogije. Sarajevo: Dobra knjiga i Centar za napredne studije.

Virág, I. (2019). The pedagogical work of Vieth and GutsMuths. Acta Educationis Generalis, 9(1), 71-77. https://doi.org/10.2478/atd-2019-0005

Volkov, G. N. (1974, 1999). Etnopedagogika. Csebokszari (1974), Moszkva (1999). 